\title{
Beauty food activities of Polygala japonica Houtt.
}

\author{
Ye-Jin Kim ${ }^{1} \cdot$ Beom-Su Park $^{1} \cdot$ So-Young Son ${ }^{1} \cdot$ Ja-Young Yun $^{1} \cdot$ Young-Je Cho $^{1}$ (D)

\section{영신초(Polygala japonica Houtt.)의 미용 식품 활성}

\author{
김예진 ${ }^{1}$ · 박범수 ${ }^{1}$ · 손소영 ${ }^{1}$ 윤자영 ${ }^{1}$ 조영제 ${ }^{1}$
}

Received: 7 December 2017 / Accepted: 2 February 2018 / Published Online: 31 March 2018

(C) The Korean Society for Applied Biological Chemistry 2018

\begin{abstract}
The objective of this study was to identify beauty food activity of Polygala japonica Houtt., which were widely used as a folk medicinal plant to treat inflammatory diseases. Both hot water and $50 \%$ ethanol extract of $P$. japonica Houtt. were evaluated for their anti-oxidant, whitening, anti-wrinkle and antiinflammatory effect based on their phenolic concentration. To measure anti-oxidant activity, four experiments were carried out. 1,1-diphenyl-3-picrylhydrazyl, 2,2-azinobis (3-ethylbenzothiazoline-6-sulfonic acid) and thiobarbituric acid reactive substances all showed more than $80 \%$ efficacy in both hot water and $50 \%$ ethanol extract of $P$. japonica Houtt. and likewise antioxidant protection factor value more than 2 . To investigate the whitening effect of P. japonica Houtt., the inhibition effect of tyrosinase on hot water and $50 \%$ ethanol extract was inhibited by 12.46 and $22.10 \%$, respectively. To examine the anti-wrinkle effect, the inhibition effect of elastase and collagenase on hot water and 50\% ethanol extract were inhibited by $28.28,58.36 \%$ and 59.73 , $78.90 \%$ respectively. To investigate the anti-inflammatory effect and moisturizing effect by hyaluronidase inhibitory effect, hot water and $50 \%$ ethanol extract were 35.65 and $86.80 \%$, respectively. The result of all the above experiments show values at a concentration of $200 \mu \mathrm{g} / \mathrm{mL}$, and based on these experimental

Young-Je Cho $(\bowtie)$

E-mail: yjcho@knu.ac.kr

${ }^{1}$ School of Food science \& Biotechnology/Food \& Bio-Industry Research Institute, Kyungpook National University, 80 University Street, Bukgu, Daegu 41566, Republic of Korea

This is an Open Access article distributed under the terms of the Creative Commons Attribution Non-Commercial License (http://creativecommons. org/licenses/by-nc/3.0/) which permits unrestricted non-commercial use, distribution, and reproduction in any medium, provided the original work is properly cited.
\end{abstract}

results, $P$. japonica Houtt. can be expected as a functional material in beauty foods.

Keywords Anti-inflammatory · Anti-oxidant · Anti-wrinkle Polygala japonica Houtt. · Whitening

\section{서 론}

영신초(Polygala japonica Houtt.)는 원지과(polygalaceae)에 속 하는 여러해살이 풀인 애기풀의 잎과 줄기를 말린 것을 말하며, 우리나라 전국 각지의 해가 잘 드는 산기슭 및 언덕에서 자란 다. 가는 여러 대가 모여 단단한 줄기는 그 높이가 $20 \mathrm{~cm}$ 정도 이며, 잎은 타원형으로 길이가 $2 \mathrm{~cm}$ 로 줄기와 더불어 잔털이 있 다. 연한 자주색의 꽃은 줄기 상부에서 4-5월경에 피고, 꽃받침 잎은 5장이지만 양 쪽의 두 장은 날개처럼 생겨 나비와 같은 형상을 가진다(Lim과 Do 2001). 영신초는 예로부터 천식을 억 제하고 지혈작용이 있으며, 정신을 안정시키는 효과가 있다고 알려져 있다. 또한, 민간에서는 술에 넣어 매일 규칙적으로 복 용하면 골수염, 골관절 결핵 등을 치료하는데 사용되었다고 알 려져 있다(Wang 등, 2008). 최근 심장병, 면역질환, 암 등과 같 은 성인병 발병 원인이 활성산소로 인한 세포의 손상이라는 연 구들이 보고됨에 따라, 신체의 노화를 지연시킬 뿐만 아니라 성 인병의 발병률도 감소시켜 주는 항산화 물질에 대한 관심이 증 가하고 있으며 이에 따른 연구활동도 활발한 추세이다(Sies 1997). 또한, 21 세기에는 두 가지 이상의 기능을 가지는 기능성 식품 및 화장품들이 출시되면서 고령화 시대에 알맞은, 보다 젊 고 건강한 삶을 위한 제품 개발 시장이 매년 증가하고 있다 (Song과 Kim 2009a; b).

영신초는 현재까지 항우울(Lee와 Chung 2011), 항염증(Kou 등, 2006) 효과 및 성분 분석(Zhang 등, 1996)에 관한 연구가 
활발히 진행되고 있지만, 미용식품에 대한 활성은 밝혀진 바가 없다. 하지만 영신초에는 항산화, 항염증, 심혈관 보호기능 등 의 다양한 생리활성을 가지는 astragalin, kaempferol (Kim 등, 2000), $\beta$-sitosterol ( $\mathrm{Li}$ 등, 1996), isorhamnetin (Kim 등, 2009b), polygalatol (Zhang과 Shan 2005), coumaric acid (Fu 등 2008) 등의 성분들이 존재한다고 보고되어 미용식품 활용 가능성을 기 대해 볼 수 있다. 특히 야생화를 미용식품의 소재로 활용한 사 례는 드물고, 화장품 업계에서도 최근 야생화 등의 천연 식품 및 식물 자원을 활용 하는 것을 추진하고 있다(Han 등, 2016). 따라서, 본 연구에서는 야생화의 일종인 영신초로부터 phenol성 물질을 분리하여 항산화 효과에 대한 기초자료를 얻고, 더 나 아가 주름 개선 활성을 보기 위한 elastase, collagenase 저해활 성 측정, 미백 효과를 위한 tyrosinase, 항염증 효과를 위한 hyaluronidase 저해 활성의 측정을 통하여 미용식품 활용 가능 성을 알아보고자 하였다.

\section{재료 및 방법}

\section{실험 재료}

본 실험에서 사용한 영신초(Polygala japonica Houtt.)는 약재형 태로 시중 한약재상에서 판매되는 것을 구입하여 $50{ }^{\circ} \mathrm{C} \mathrm{dry}$ oven (FO-600M, Jeiotech, Daejeon, Korea)에서 건조한 후 40 $\mathrm{mesh}$ 로 분쇄해서 분말화 하여 사용하였으며, $4{ }^{\circ} \mathrm{C}$ 냉장보관 하 면서 실험에 시료로 사용하였다.

\section{영신초 추출물의 제조}

영신초 열수 추출물은 건조 영신초 분말 $1 \mathrm{~g}$ 에 증류수 $200 \mathrm{~mL}$ 를 가한 다음 용액이 $100 \mathrm{~mL}$ 가 될 때까지 가열, 증발시킨 후 냉각하여 24시간 동안 상온에서 교반 추출하였으며, ethanol 추 출물은 영신초 분말 $1 \mathrm{~g}$ 에 $50 \%$ ethanol $100 \mathrm{~mL}$ 를 추출용매로 가하여 24 시간 동안 상온에서 교반 추출하였다. 각 추출물은 Whatman No. 1 filter paper (Whatman Inc., Piscataway, NJ, USA)로 여과한 후 rotary vacuum evaporator (Eyela NE, Tokyo, Japan)에서 농축하여 추출물의 phenolic compounds를 $50-200 \mu \mathrm{g} / \mathrm{mL}$ 농도로 맞추어 사용하였다.

\section{Total phenolic compounds의 함량 측정}

Total phenolic compounds의 함량 측정은 Folin과 Denis의 방 법(Folin과 Denis 1912) 에 준하여 측정하였으며, 시료액 $1 \mathrm{~mL}$ 에 $95 \%$ ethanol $1 \mathrm{~mL}$ 와 증류수 $5 \mathrm{~mL}$ 를 첨가하고 $1 \mathrm{~N}$ FolinCiocalteu reagent (Junsei, Tokyo, Japan) $0.5 \mathrm{~mL}$ 를 넣어 잘 섞어주고 5 분간 방치한 후, $5 \% \mathrm{Na}_{2} \mathrm{CO}_{3} 1 \mathrm{~mL}$ 를 가하였다. 이 혼합액을 1 시간 동안 암실에서 방치한 후 분광 광도계(UV/Vis spectrophotometer, Jasco, Tokyo, Japan)를 사용하여 $725 \mathrm{~nm}$ 에 서 흡광도를 측정하였다. Total phenolic compounds는 gallic acid (Sigma-Aldrich Co. St. Louis, MO, USA)를 이용한 표준 곡선을 통해 양을 환산하였다.

\section{항산화능 측정}

항산화능은 1,1-diphenyl-2-picrylhydrazyl (DPPH), 2.2-azinobis (3-ethylbenzothiazoline-6-sulfonic acid) (ABTS), antioxidant protection factor $(\mathrm{PF})$, thiobarbituric acid reactive substances (TBARs) 실험을 통하여 측정하였다. DPPH radical에 대한 소 거활성은 $\mathrm{Blios}(1958)$ 의 방법에 준하여 측정하였으며, 각 시료 $1 \mathrm{~mL}$ 에 $60 \mu \mathrm{M}$ DPPH $3 \mathrm{~mL}$ 를 넣고 vortex한 후 15 분간 방치 한 다음 $517 \mathrm{~nm}$ 에서 흡광도를 측정하였다. 저해율 $(\%)$ 은 (1-시 료의 흡광도/대조구의 흡광도) $\times 100$ 으로 계산하였다. ABTS radical cation decolorization의 측정은 Fellegrin 등(1999)의 방 법에 준하여 측정하였고, $7 \mathrm{mM}$ ABTS $5 \mathrm{~mL}$ 와 $140 \mathrm{mM}$ $\mathrm{K}_{2} \mathrm{~S}_{2} \mathrm{O}_{8} 88 \mathrm{~mL}$ 를 혼합하여 만든 $\mathrm{ABTS}$ stock $1 \mathrm{~mL}$ 와 $50 \%$ ethanol $88 \mathrm{~mL}$ 를 섞어 만든 $\mathrm{ABTS}$ solution에 시료액을 넣어 vortex한 후 1.5 분간 incubation하고 $734 \mathrm{~nm}$ 에서 흡광도를 측정 하였다. 저해율 $(\%)$ 은 (1-시료의 흡광도/대조구의 흡광도 $) \times 100$ 으 로 계산하였다. PF는 Andarwulan과 Shetty(1999)의 방법에 준 하여 측정하였으며, $\beta$-carotene $30 \mathrm{mg}$ 과 chloroform $50 \mathrm{~mL}$ 의 혼합액 $1 \mathrm{~mL}$ 를 evaporator용 수기에 분주하여 $40{ }^{\circ} \mathrm{C}$ 의 rotary vacuum evaporator (Eyela NE, Tokyo, Japan)에서 chloroform 을 증류시킨 후 linoleic acid $20 \mu \mathrm{L}$, tween $40184 \mu \mathrm{L}, \mathrm{H}_{2} \mathrm{O}_{2}$ $50 \mathrm{~mL}$ 를 가하여 만든 emulsion에 시료를 혼합하여 암실상태인 $50{ }^{\circ} \mathrm{C}$ water bath에서 30 분간 반응시켜 $470 \mathrm{~nm}$ 에서 흡광도를 측정하였다. $\mathrm{PF}$ 는 시료의 흡광도/대조구의 흡광도 비로 계산하 였다. TBARs 측정은 Buege와 Aust(1978)의 방법에 준하여 측 정하였으며, $1 \%$ linoleic acid와 $1 \%$ tween 40으로 만든 emulsion을 시료와 혼합하여 $50{ }^{\circ} \mathrm{C}$ water bath에서 10 시간 이상 반응시킨 후, 반응액 $1 \mathrm{~mL}$ 에 TBA/TCA 시약 $2 \mathrm{~mL}$ 를 가하고 15 분간 $2,000 \mathrm{rpm}$ 으로 원심분리한 상징액의 흡광도를 $532 \mathrm{~nm}$ 에 서 측정하였다. 저해율 $(\%)$ 은 (1-시료의 TBARs $\mu \mathrm{M} /$ 대조구의 TBARs $\mu \mathrm{M}) \times 100$ 으로 계산하였다. 시료의 항산화능은 합성 항 산화제로 널리 알려진 butylated hydroxy toulene (BHT)를 positive control로 사용하여 비교하였다.

\section{Tyrosinase 저해활성 측정}

Tyrosinase 저해활성 측정은 Hearing VJ(1987)의 방법에 준하여 측정하였다. 반응구에는 $0.1 \mathrm{M}$ sodium phosphate buffer $(\mathrm{pH}$ 6.8) $2.3 \mathrm{~mL}$ 와 기질액 $1.5 \mathrm{mM}$ L-tyrosine 용액 $0.4 \mathrm{~mL}$ 의 혼합 액에 $250 \mathrm{U} / \mathrm{mL}$ mushroom tyrosinase (Sigma-Aldrich Co., St.) $0.1 \mathrm{~mL}$ 와 시료를, 대조구에는 시료 대신 증류수를 $0.2 \mathrm{~mL}$ 씩 첨 가하여 $37^{\circ} \mathrm{C}$ 에서 20 분간 반응시킨 후 흡광도 $475 \mathrm{~nm}$ 에서 측 정하였다. 저해율 $(\%)$ 은 (1-반응구의 흡광도/대조구의 흡광도)× 100 으로 계산하였다.

\section{Elastase 및 collagenase 저해활성 측정}

Elastase 저해활성 측정은 James 등(1996)의 방법에 준하여 측 정하였다. 반응구는 $0.2 \mathrm{M}$ Tris- $\mathrm{HCl}$ buffer $(\mathrm{pH} 8.0) 1 \mathrm{~mL}$ 와 기질액 $0.8 \mathrm{mM} \mathrm{N}$-succinyl-(Ala) $)_{3}$ - $\rho$-nitroanilide 용액 $0.1 \mathrm{~mL}$ 의 혼합액에 $1.0 \mathrm{U} / \mathrm{mL}$ porcine pancreatic elastase (PPE) (SigmaAldrich Co.) 효소용액 $0.1 \mathrm{~mL}$ 와 시료를, 대조구에는 시료 대 신 증류수를 $0.1 \mathrm{~mL}$ 씩 첨가하여 $25^{\circ} \mathrm{C}$ 에서 20 분간 반응시킨 후, $\rho$-nitroaniline 생성량을 흡광도 $410 \mathrm{~nm}$ 에서 측정하였다. 저해율 $(\%)$ 은 (1-반응구의 흡광도/대조구의 흡광도) $\times 100$ 으로 계산하였 다. Collagenase 저해활성 측정은 Wunsch와 Heidrich(1963)의 방법에 준하여 측정하였다. 반응구는 $0.1 \mathrm{M}$ Tris- $\mathrm{HCl}$ buffer $(\mathrm{pH} 7.5)$ 에 $4 \mathrm{mM} \mathrm{CaCl} 2$ 를 첨가하여 4-phenylazobenzyl oxycarbonyl- 
Table 1 Condition for operating HPLC in the analysis of Polygala japonica Houtt.

\begin{tabular}{ll}
\hline \hline Instrument & HP HPLC series 1100. Hewlett Packard, \\
& Waldbronn, Germany \\
Column & Nova-Pak C18 $(3.9 \times 150 \mathrm{~mm})$ Column \\
Column temp & $30{ }^{\circ} \mathrm{C}$ \\
Injection volume & $20 \mathrm{~L}$ \\
Mobile phase & $\mathrm{A}: \mathrm{H}_{2} \mathrm{O}, \mathrm{B}: 100 \%$ Methanol $(\mathrm{A}: \mathrm{B}=30: 70)$ \\
Flow rate & $0.2 \mathrm{~mL} / \mathrm{min}$ \\
Retention time & $25 \mathrm{~min}$ \\
Detection & $230 \mathrm{~nm}$ \\
\hline
\end{tabular}

Pro-Leu-Gly-Pro-D-Arg $(0.3 \mathrm{mg} / \mathrm{mL})$ 를 녹인 기질액 $0.25 \mathrm{~mL}$ 와 시료 $0.1 \mathrm{~mL}$ 의 혼합용액에 $0.2 \mathrm{mg} / \mathrm{mL}$ collagenase (SigmaAldrich Co.) $0.15 \mathrm{~mL}$ 를 첨가하고, 대조구에는 시료 대신 증류 수 $0.1 \mathrm{~mL}$ 를 첨가하여 실온에서 20 분간 방치한 후 $6 \%$ citric acid $0.5 \mathrm{~mL}$ 를 넣어 반응을 정지시키고, ethyl acetate $2 \mathrm{~mL}$ 를 첨가하고 $320 \mathrm{~nm}$ 에서 흡광도를 측정하였다. 저해율 $(\%)$ 은 (1-반 응구의 흡광도/대조구의 흡광도) $\times 100$ 으로 계산하였다.

\section{Hyaluronidase 저해활성 측정}

Hyaluronidase 저해활성 측정은 Dorfman과 Ott(1948)의 방법에 준하여 측정하였다. 반응구는 $20 \mathrm{mM}$ sodium phosphate buffer (pH 6.9)에 녹인 hyaluronidase $(1,000 \mathrm{U} / \mathrm{mL}) \quad 0.5 \mathrm{~mL}$ 와 $0.3 \mathrm{M}$ phosphate buffer ( $\mathrm{pH}$ 5.3)에 녹인 substrate $(4 \mathrm{mg} / \mathrm{mL}) \quad 0.5$ $\mathrm{mL}$ 를 시료 $0.5 \mathrm{~mL}$ 에 넣어 $38^{\circ} \mathrm{C}$ 에서 50 분간 반응시킨 후 0.04 $\mathrm{M}$ acetate buffer ( $\mathrm{pH}$ 3.75)에 녹인 알부민 용액 $5 \mathrm{~mL}$ 를 첨가 한 다음 5 분간 방치하고 $600 \mathrm{~nm}$ 에서 투과율을 측정하였다. 대 조구는 시료 대신 증류수 $0.5 \mathrm{~mL}$ 를 넣어 반응시켰다. 저해율 $(\%)$ 은 (1-반응구의 투과율/대조구의 투과율) $\times 100$ 으로 계산하였다.

\section{HPLC를 이용한 phenolic profile 분석}

본 실험에 사용된 영신초 열수 추출물과 $50 \%$ 에탄올 추출물을 HPLC용 메탄올로 1:1000으로 희석하여 syringe filter $(13 \mathrm{~mm}$ $\mathrm{GD} / \mathrm{X}$ disposable filter device, $0.2 \mu \mathrm{m}$ pore size, Whatman)로 여과한 후 HPLC (HP series 1100, Hewlett Packard, Walbronn, Germany)로 분석하였으며, HPLC 분석조건은 Table 1과 같다.

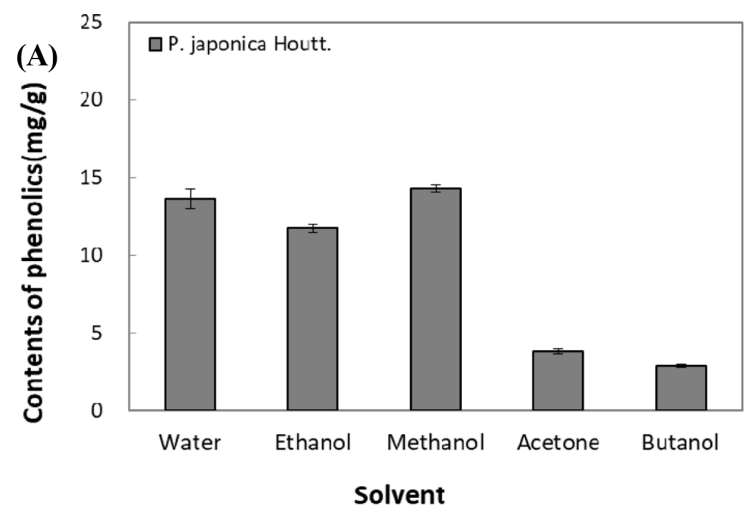

\section{통계처리}

본 실험은 3 회 반복하여 측정하였고, 자료의 통계처리는 SPSS 22 for windows (Statistical Package for Social Science, Chicago, IL, USA) 프로그램을 이용하여 평균 \pm 표준편차(mean \pm standard deviation)로 표시하였다. 시료 간의 유의차는 분산분 석(ANOVA)과 Duncan의 다중범위검정(Duncan's multiple range test)을 실시하여 $95 \%$ 신뢰구간에서 검증하였다.

\section{결과 및 고찰}

\section{Total phenolic compounds의 함량 측정}

Phenolic compounds는 하나 또는 둘 이상의 수산기로 치환된 방향족환을 가지고 있는 식물성분을 말하는 것으로, 식물체에 특수한 색깔을 부여하고 산화환원 반응 시 기질로 작용하며 미 생물의 공격을 막아 식물 자체를 보호하고 식품 고유의 맛과 향기에도 관여한다(Alsalvar 등, 2001). 영신초의 total phenolic compounds를 추출하기 위해서 열수, 에탄올, 메탄올, 아세톤, 부 탄올을 이용하여 용매별 phenolic compound의 용출율을 확인하 였다(Fig. 1A). 그 결과, 용매별로 추출하였을 때 열수, 에탄올 메탄올, 아세톤, 부탄올 등의 순으로 각각 $13.62,11.75,14.29$, $3.85,2.90 \mathrm{mg} / \mathrm{g}$ 을 나타냈으며, 메탄올에서 가장 높은 용출량을 보였다. 하지만 미용식품의 소재로 이용하기에는 상대적으로 안 전한 용매인 열수와 에탄올을 사용하는 것이 바람직하다고 판 단되어, $10-100 \%$ 의 에탄올 농도구간에서 추출을 위한 최적 농 도를 결정하였다(Fig. 1B). 그 결과, $50 \%$ 에탄올 추출물에서 phenolic compounds가 가장 높게 나타나, $50 \%$ 에탄올 추출물 과 열수 추출물을 사용하는 것이 가장 효과적이라고 판단되었다.

\section{항산화능 활성}

영신초 추출물의 항산화능은 $\mathrm{DPPH}, \mathrm{ABTS}, \mathrm{PF}, \mathrm{TBARs}$ 활성 을 근거로 평가하였다. DPPH법은 sulfur-containing amino acid 와 $\mathrm{BHA}$ 등의 항산화제에 의해 환원 및 탈색되는 원리를 이용 한 실험으로, 천연물로부터 추출된 수용성 항산화 물질을 탐색 하는데 많이 사용되고 있다. $50-200 \mu \mathrm{g} / \mathrm{mL}$ 의 농도구간으로 맞 춘 영신초 추출물의 항산화능을 $\mathrm{DPPH}$ 법으로 측정한 결과, Fig. $2 \mathrm{~A}$ 와 같이 나타났다. $200 \mu \mathrm{g} / \mathrm{mL}$ 농도에서 열수 추출물과 $50 \%$

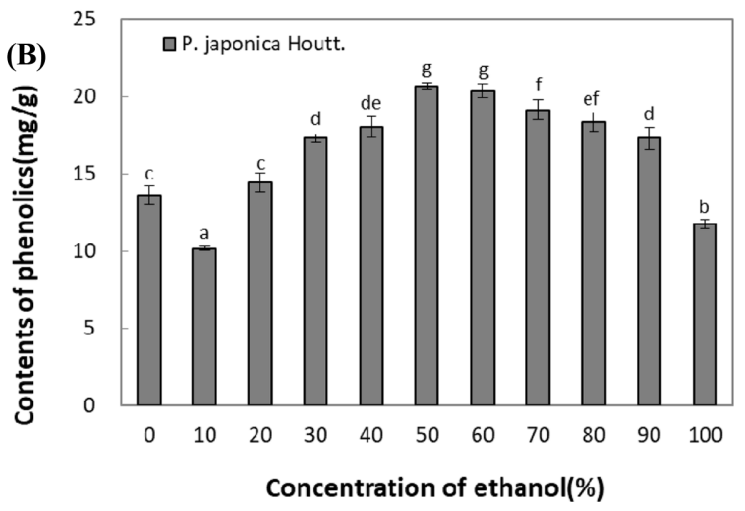

Fig. 1 The content of phenolic compounds in the effect of various solvents (A) and ethanol concentration (B) on extraction of phenolic from Polygala japonica Houtt.. Means with different superscript letters are significantly different at $p<0.05$ by a Ducan's multiple range tests ( $\mathrm{n}=3$ ) 

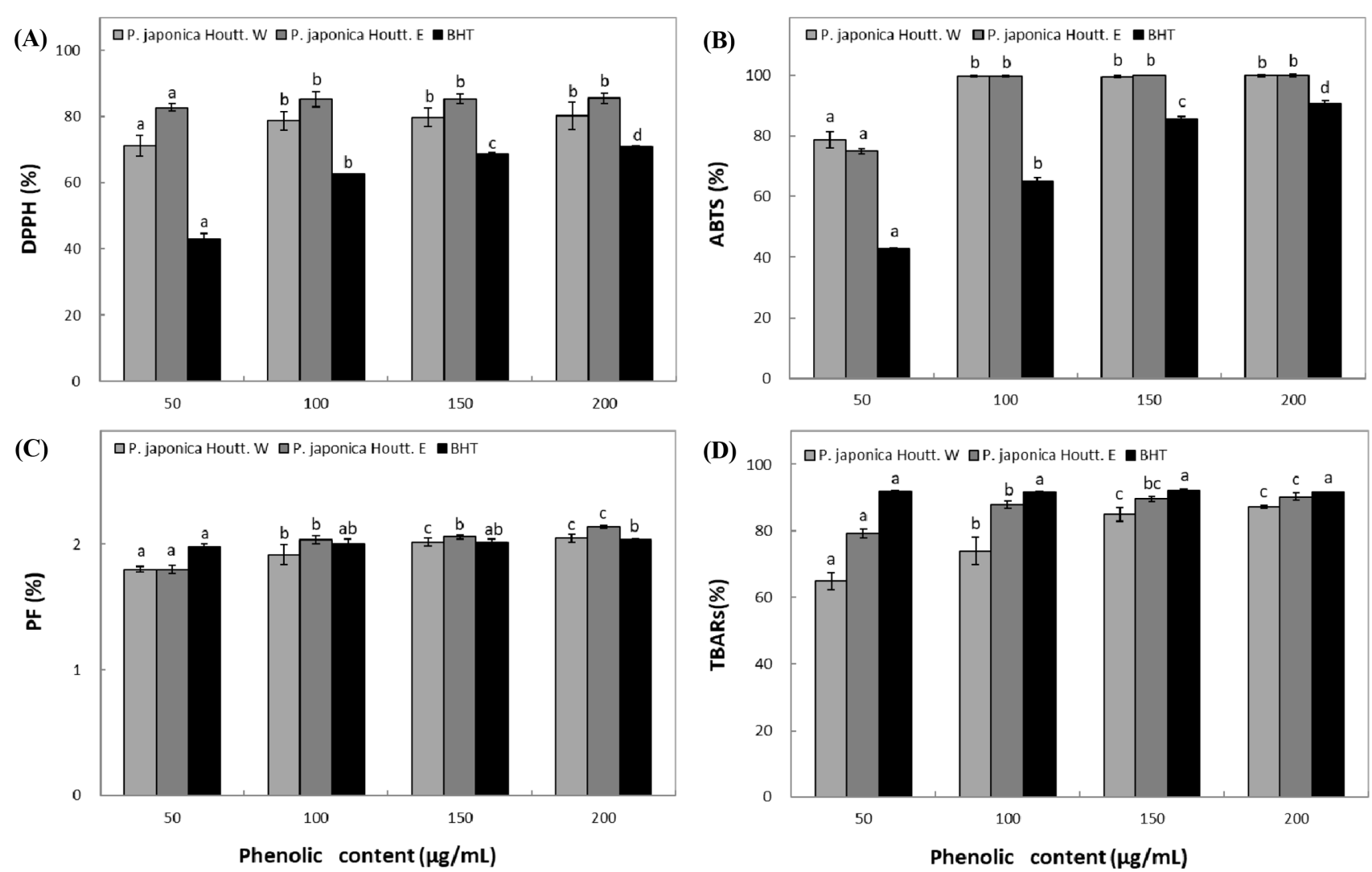

Fig. 2 Antioxidant activity of water and ethanol extracts from Polygala japonica Houtt. (A): DPPH, (B): ABTS, (C): PF, (D): TBARs, W: water extracts, E : 50\% ethanol extracts. Means with different superscript letters are significantly different at $p<0.05$ by a Ducan's multiple range tests (n=3)

에탄올 추출물 모두 $80 \%$ 가 넘는 저해율을 보였고, 동일한 농 도의 BHT는 $70.96 \%$ 의 저해율을 나타낸 것을 미루어 보았을 때, 영신초의 항산화능이 합성 항산화제인 BHT 보다 우수한 것 을 알 수 있었다. ABTS법은 ABTS와 potassium persulfate에 의해 생성된 $\mathrm{ABTS}+$ radical을 분해한 후 측정하여 항산화능을 알아보는 실험으로 친유성, 친수성 항산화제에 모두 사용 가능 하다고 알려져 있다(So 2015). $50-200 \mu \mathrm{g} / \mathrm{mL}$ 의 농도구간으로 맞춘 영신초 추출물의 항산화능을 $\mathrm{ABTS}$ 법으로 측정한 결과, Fig. 2B에서와 같이 나타났다. $100 \mu \mathrm{g} / \mathrm{mL}$ 농도에서 열수와 $50 \%$ 에탄올 추출물 모두 $99 \%$ 이상의 높은 항산화능을 보이며, 동일한 농도의 BHT는 $65.22 \%$ 의 저해율을 나타낸 것을 미루어 보았을 때, 영신초의 항산화능이 합성 항산화제보다 우수하다는 것을 알 수 있었다. $\mathrm{PF}$ 법은 $\beta$-carotene과 지질 산화 과정의 부 산물인 peroxy radical이 반응하여 생성된 inactive products가 free radical에 의한 연쇄반응을 중단시키는 원리를 이용하여 시 료에 대한 지용성 항산화 물질을 탐색하는 실험이다. $50-200 \mu \mathrm{g} /$ $\mathrm{mL}$ 의 농도구간으로 맞춘 영신초 추출물의 항산화능을 $\mathrm{PF}$ 법으 로 측정한 결과, Fig. $2 \mathrm{C}$ 에서와 같이 $200 \mu \mathrm{g} / \mathrm{mL}$ 의 농도구간에 서 열수와 $50 \%$ 에탄올 추출물 모두 $2.00 \mathrm{PF}$ 이상의 높은 항 산화능을 보였으며, 영신초에 지용성 항산화 물질이 풍부하다는 것을 알 수 있었다. TBARs법은 2-thiobarbituric acid (TBA) 시약이 불포화 지방산 자동산화의 부산물인 malondialdehyde와 반응하여 생성된 적색 복합체의 함량을 측정하여 항산화능을 확 인하는 실험이다(Cojocaru 등, 2004; Cheon 등, 2008). 50-200 $\mu \mathrm{g} / \mathrm{mL}$ 의 농도구간으로 맞춘 영신초 추출물의 항산화능을 TBARs법으로 측정한 결과, Fig. 2D에서와 같이 열수와 $50 \%$ 에탄올 추출물 모두 $200 \mu \mathrm{g} / \mathrm{mL}$ 의 농도에서 각각 87.30 , $90.27 \%$ 로 높은 항산화능을 보였다. 항산화능을 알아 보기 위해 실시한 위의 4 가지 실험 결과들을 통하여 영신초 열수 및 $50 \%$ 에탄올 추출물에 존재하는 phenol성 물질들의 항산화 작용으로 인해 인체내의 free radical을 소거함으로써 천연 항산화제로서 의 기능이 우수함이 증명되었으며, 미용식품 소재로서의 활용 가능성을 확인할 수 있었다.

\section{Tyrosinase 저해활성}

자외선으로부터 피부를 보호해주기 위해 생성되는 eumelanin, phenomelanin 등의 melanin은 피부 색에 영향을 미친다 (Kazumasa와 Shosuke 2002). 피부 색의 변화는 melanin 세포 수의 변화, melanosome의 생산이나 구조의 이상, melanosome 의 melanism 등 여러가지 요인에 의하여 결정된다(Kim과 Lee 2007). 이러한 melanin은 L-tyrosine을 기질로 하는 효소, tyrosinase의 산화과정을 통해 최종적으로 생성되는 물질로 피부 를 검게 만든다(Pak 등, 2016). 따라서, tyrosinase 저해활성을 측정하여 영신초가 가지는 미백효과를 알아볼 수 있다. 본 실 험에서 영신초 추출물의 tyrosinase 저해활성을 측정한 결과, Fig. 3에서와 같이 열수 추출물은 $200 \mu \mathrm{g} / \mathrm{mL}$ 의 농도구간에서 저 해율이 $12.36 \%, 50 \%$ 에탄올 추출물은 동일한 농도구간에서 저 해율이 $22.10 \%$ 로 영신초 $50 \%$ 에탄올 추출물의 미백효과가 열 


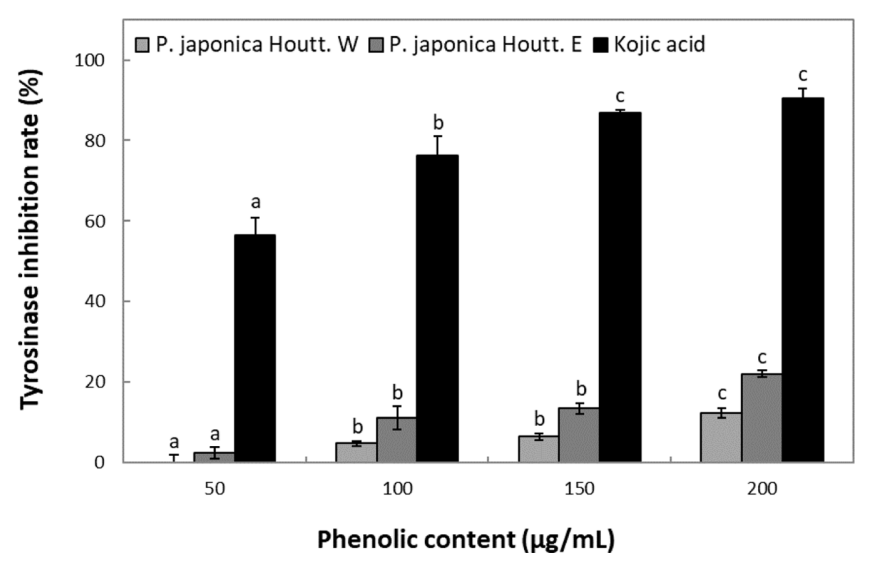

Fig. 3 Inhibitory effect of water and ethanol extracts from Polygala japonica Houtt. on tyrosinase. Ethanol extract showed higher tyrosinase inhibitory effect than water extract. Means with different superscript letters are significantly different at $p<0.05$ by a Duncan's multiple range tests $(n=3)$

수에 비해 다소 높은 것으로 나타났다. 하지만 $200 \mu \mathrm{g} / \mathrm{mL}$ 의 농 도구간에서 positive control로 사용한 kojic acid의 저해율이 $90.45 \%$ 를 나타낸 것으로 보아 영신초의 열수 및 $50 \%$ 에탄올 추출물은 미백효과를 나타내는 tyrosinase 저해활성이 다소 낮 은 것으로 판단되었다.

\section{Elastase 및 collagenase 저해활성}

Collagen과 결합된 상태로 존재하는 elastin은 진피의 피부 탄력 을 유지하는데 중요한 기질 단백질이다. Elastase 효소는 이러 한 elastin을 분해하여 주름을 생성시키는 주요 원인으로 알려 져 있으므로, elastase 저해활성을 측정하여 피부의 주름개선 효 과를 알아볼 수 있다(Lee 등, 1999). 영신초 추출물의 elastase 저해활성을 측정한 결과, Fig. $4 \mathrm{~A}$ 에서와 같이 $50-200 \mu \mathrm{g} / \mathrm{mL}$ 의 농도구간에서 열수 추출물은 $6.33-28.28 \%, 50 \%$ 에탄올 추출물 은 그 보다 더 높은 32.64-58.36\%를 나타내어 농도의존적으로 elastase 저해활성이 증가하는 양상을 보였다. 따라서 $50 \%$ 에탄
올 추출물이 열수 추출물보다 주름개선 효과가 더 뛰어난 것을 알 수 있었다.

세포 외 기질의 주요 구성성분인 collagen은 피부의 탄력과 보습을 높여주는 기질 단백질로(Perlish 등, 1988; Kim 등, 2009a), 단백질 분해효소인 collagenase에 의해서만 파괴되며 (Demina와 Lysenko 1996), 이에 의해 collagen이 파괴되거나 결핍이 되면 주름을 생성시킨다 $(\mathrm{Kim}$ 등, 2008). 따라서, collagenase의 저해활성을 측정하여 피부의 주름개선 효과를 알 아볼 수 있다. 영신초 추출물의 collagenase 저해활성을 측정한 결과, Fig. $4 \mathrm{~B}$ 에서와 같이 열수 추출물은 $50-200 \mu \mathrm{g} / \mathrm{mL}$ 의 농도 구간에서 저해율은 $25.89-59.73 \%$ 로 증가하였고, $50 \%$ 에탄올 추 출물의 경우 동일한 농도구간에서 저해율이 $46.40-78.90 \%$ 로 통 계적으로 유의적인 차이를 보이며, 농도 의존적으로 증가하는 것을 볼 수 있었다. 특히, positive control로 사용된 epigallocatechin gallate는 강력한 항산화 작용과 다양한 피부개선 효능 을 가지는 것으로 알려져 있으며, 이와 $50 \%$ 에탄올 추출물을 비교하였을 때 $200 \mu \mathrm{g} / \mathrm{mL}$ 의 농도에서 각각 $77.84,78.90 \%$ 의 저해율을 보이며 유사하게 나타났다(Hu 등, 2013). 따라서, $50 \%$ 에탄올 추출물은 피부 주름개선에 우수한 효과를 가지며 미용 식품 소재로서 이용 가능성을 제시할 수 있다.

\section{Hyaluronidase 저해활성}

Hyaluronic acid는 glucuronic acid와 glucosamine이 연속적으로 결합된 고분자 다당류이다(Meyer 1947). 고분자 형태의 hyaluronic acid는 macrophage의 phagocytic activity를 저해하여 염증을 억 제하지만, hyaluronic acid의 분해효소인 hyaluronidase에 의해 저분자 형태가 되면 상처를 회복하는 과정에서 염증을 일으키 게 된다(Girish와 Kemparaju 2007). 따라서, hyaluronidase 저 해활성을 측정하여 영신초 추출물이 가지는 항염증 효과를 알 아보고자 하였다. 영신초 추출물의 hyaluronidase 저해활성을 측 정한 결과, Fig. 5 에서와 같이 $50-200 \mu \mathrm{g} / \mathrm{mL}$ 의 농도구간에서 열 수 추출물과 $50 \%$ 에탄올 추출물은 각각 $11.49-35.65,10.16-$ $86.80 \%$ 의 저해율을 나타내었고, 모두 통계적으로 유의적인 차 이를 보이며 농도 의존적으로 증가하는 것을 볼 수 있었다. 영
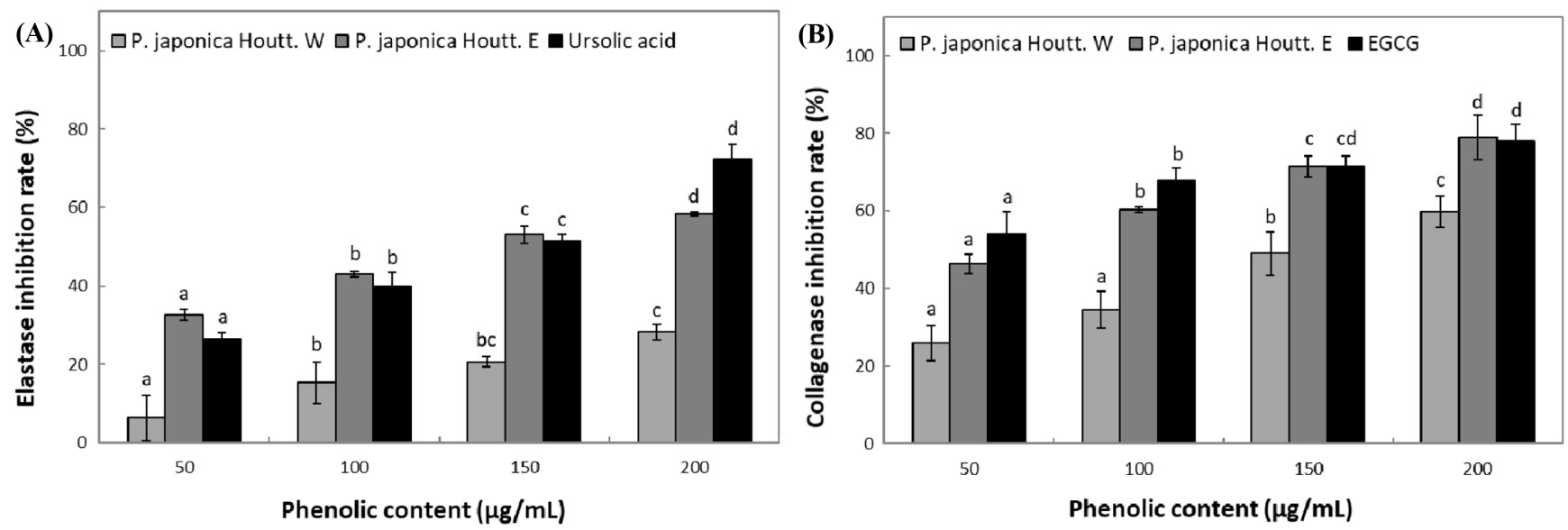

Fig. 4 Inhibitory effect of water and ethanol extracts from Polygala japonica Houtt. on elastase (A) and collagenase (B). Ethanol extract showed higher elastase and collagenase inhibitory effect than water extract. Means with different superscript letters are significantly different at $p<0.05$ by a Duncan's multiple range tests $(n=3)$ 


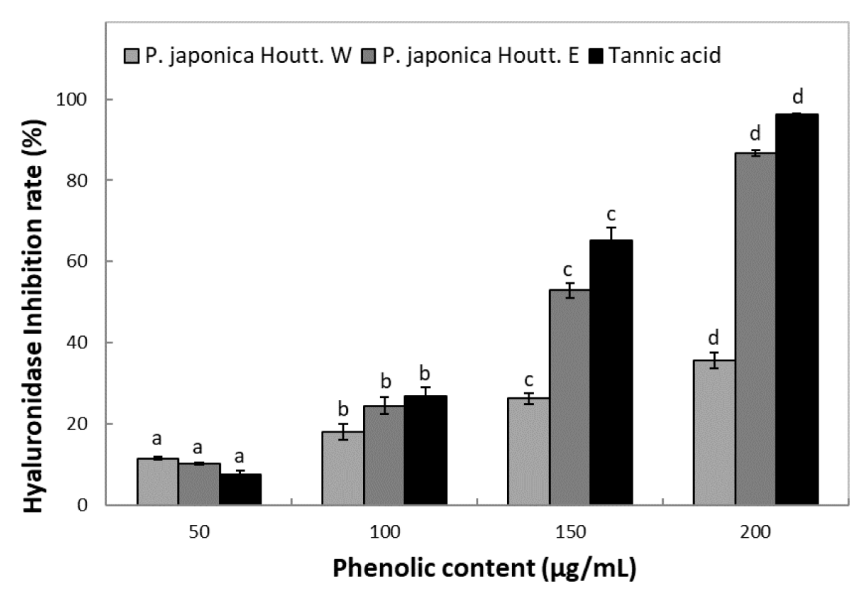

Fig. 5 Inhibitory effect of water and ethanol extracts from Polygala japonica Houtt. on hyaluronidase. Ethanol extract showed higher hyaluronidase inhibitory effect than water extract. Means with different superscript letters are significantly different at $p<0.05$ by a Duncan's multiple range tests $(n=3)$

신초는 구내염, 골수염, 간염 등의 염증반응에 민간요법으로 널 리 이용되어 온 만큼(Kou 등, 2006), 위의 실험으로 $50 \%$ 에탄 올 추출물의 항염증 효과가 매우 우수하다는 것을 확인할 수 있었다. 또한 고분자의 hyaluronic acid는 피부 내 수분함량을 유지해주는 보습효과를 가진다고 알려져 있다(Seo 1988). 따라 서, 위의 실험 결과를 통해 영신초 추출물이 hyaluronidase의 저 해 활성을 가지고, 그에 따라 항염증 및 보습효과를 가지는 미
용식품의 소재로서의 활용 가능성을 제시할 수 있었다.

\section{HPLC를 이용한 phenolic profile 분석}

HPLC를 이용한 영신초 열수 추출물의 chromatogram에서 retention time 4.4, 5.2분에 peak가 두드러지게 나타났고, retention time 8.5 분에서 peak가 얕게 나타났다(Fig. 6A). 반면 영신초 $50 \%$ 에탄올 추출물의 chromatogram에서는 retention time 4.6, 5.3분의 peak가 열수 추출물의 peak보다 2배 이상 높 게 나타났으며 retention time 8.5 분의 peak는 열수 추출물의 peak보다 10 배 이상 높게 나타났다(Fig. 6B). 결국 영신초 열수 및 $50 \%$ 에탄올 추출물 간에는 추출 수율의 차이가 존재하며, 유용물질의 profile 차이도 존재하는 것으로 확인되었다. 따라서 열수와 $50 \%$ 에탄올 추출물 간의 미용 식품 활성에도 차이를 나타내는 것으로 사료되었다.

\section{초 록}

영신초의 용매별 phenolic compounds는 열수 추출물과 추출 최 적 농도인 $50 \%$ 에탄올 추출물을 이용하여 실험을 진행하였다. 영신초 열수 추출물에 대한 항산화능을 $\mathrm{DPPH}, \mathrm{ABTS}, \mathrm{PF}$, TBARs 실험으로 측정한 결과, $50-200 \mu \mathrm{g} / \mathrm{mL}$ 의 농도 구간에서 각각 $71.32-80.29 \%, 78.61-99.80 \%, 1.80-2.05 \mathrm{PF}, 64.88-87.30 \%$ 의 저해율을 나타냈고, $50 \%$ 에탄올 추출물에서는 각각 82.82 $85.66 \%, 74.88-99.90 \%, 1.80-2.14 \mathrm{PF}, 79.23-90.27 \%$ 의 저해율 을 나타냈다. 따라서, 영신초 $50 \%$ 에탄올 추출물이 열수 추출
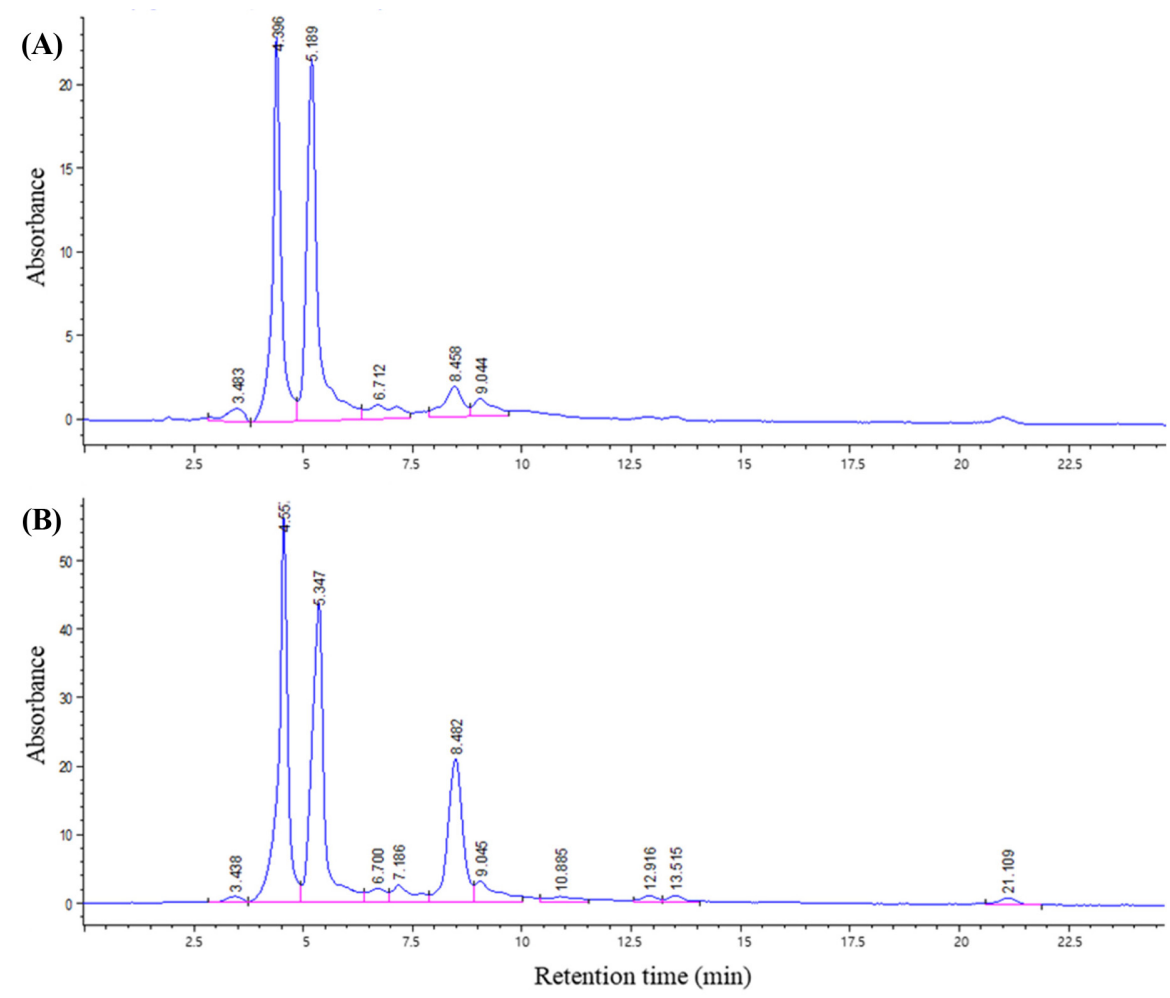

Fig. 6 HPLC chromatogram of Polygala japonica Houtt. (A; water extract, B; 50\% ethanol extract) 
물보다 항산화능이 더 우수한 것을 알 수 있었다. 영신초 열수 및 $50 \%$ 에탄올 추출물의 미용식품 활성을 알아보기 위하여 tyrosinase 저해활성, elastase 및 collagenase 저해활성, hyaluronidase 저해활성을 측정하였다. Tyrosinase 저해활성은 $200 \mu \mathrm{g} / \mathrm{mL}$ 의 농 도에서 열수와 $50 \%$ 에탄올 추출물은 각각 $12.46,22.10 \%$ 를 나 타냈다. Elastase 저해활성은 동일한 농도에서 각각 28.28 , $58.36 \%$, collagenase 저해활성은 각각 $59.73,78.90 \%$ 를 나타냈 으며, hyaluronidase 저해활성은 각각 $35.65,86.80 \%$ 를 나타냈 다. 또한 열수 추출물과 $50 \%$ 에탄올 추출물 간의 생리활성의 차이는 phenolic profile의 차이에 의한 것이라 판단되었다. 이 러한 결과에 따라, 영신초 열수 및 $50 \%$ 에탄올 추출물은 항산 화능이 높아 천연 항산화제로의 이용이 가능할 것으로 보이며, 특히 주름 개선 및 염증억제 효과가 뛰어난 것으로 나타나 기 능성 식품 및 화장품 제조에 이용 가능한 천연 미용식품 소재 로의 활용이 기대된다.

Keywords 미백 · 영신초 · 주름 개선 · 항산화 활성 · 항염증

\section{References}

Alsalvar C, Grigor JM, Quantick D, Quantick PC, Shahidi F (2001) Comparison of volatiles, phenolics, sugars, antioxidant vitamins, and sensory quality of different colored carrot varieties. J Agric Food Chem 49: $1410-1416$

Andarwulan N, Shetty K (1999) Phenolic content in differentiated tissue cultures of untransformed and agrobacterium-transformed roots of anise (Piminella anisum L.). J Agric Food Chem 47: 1776-1780

Blios MS (1958) Antioxidant determination by the use of a stable free radical Nature 26: 1199-1200

Buege JA, Aust SD (1978) Microsomal lipid peroxidation. Methods Enzymol 105: 302-310

Cheon SJ, Jang MJ, Jang YA, Choi EY, Jun DH, Kim YH, Cho WA, Jeong YS, Kwon HB, Kim TH, Choi KI, Do JR, Lee CE, Lee JT (2008) Antiwrinkle effect of Cambodian Phellinus linteus extracts. J Life Sci 18: $1718-1722$

Cojocaru IM, Cojocaru M, Musuroi C, Botezat M, Lazar L, Druta A (2004) Lipid peroxidation and catalase in diabetes mellitus with and without ischemic stroke. Rom J Intern Med 42: 423-429

Demina NS, Lysenko SV (1996) Collagenolytic enzymes synthesized by microorganisms. Mikrobiologiia 65: 293-304

Dorfman A, Ott L (1948) A turbidimetric method for the assay of hyaluronidase. J Biol Chem 172: 367-375

Fellegrin N, Ke R, Yang M, Rice-Evans C (1999) Screening of dietary carotenoids and carotenoid-rich fruit extracts for antioxidant activities applying 2,2'-azinobis (3-ethylenebenzo thiazoline-6-sulfonic acid) radical cation decolorization assay. Methods Enzymol 299: 379-389

Folin O, Denis W (1912) On phosphotungstic-phosphomolybdic compounds as color reagents. J Biol Chem 12: 239-249

Fu J, Zuo L, Yang J, Chen R, Zhang D (2008) Oligosaccharide polyester and triterpenoid saponins from the roots of Polygala japonica. Phytochemistry 69: 1617-1624

Girish KS, Kemparaju K (2007) The magic glue hyaluronan and its eraser hyaluronidase: a biological overview. Life Sci 80: 1921-1943

Han DK, Lee HJ, Lee EH, Baek HD, Shin DK, Park DS, Hwang HS, Hong WS (2016) Consumers' purchasing behavior of functional cosmetics and Inula based functional cosmetics merchandising research. Journal of the Korea academia-industrial cooperation society. 17: 236-250

Hearing VJ Jr (1987) Mammalian monophenol monooxygenase (Tyrosinase): purification, properties, and reactions catalyzed. Methods Enzymol 142: 154165

Hu B, Ting Y, Zeng X, Huang Q (2013) Bioactive peptides/ chitosan nanoparticles enhance cellular antioxidant activity of (-)epigallocatechin 3 gallate. J Agric Food Chem 61: 875-881

James AEK, Timothy DWC, Gorden L (1996) Inhibition of human leukocyte and porcin pancreatic elastase by homologues of bovine pancreatic trypsin inhibitor. Biochem J 35: 90909096

Kazumasa W, Shosuke I (2002) Advanced chemical methods in melanin determination. Pigment Cell Res 15: 174-183

Kim EK, Lee HB (2007) Functional cosmetics-whitening. New and Information for chemical engineers 25: 138-143

Kim ID, Kwon RH, Heo YY, Jung HJ, Kang HY, Ha BJ (2008) Supercritical extraction of oriental herb: anti-aging and anti-wrinkle effects. KSBB Journal 23: 529-534

Kim JK, Lee JH, Yang MS, Seo DB, Lee SJ (2009a) Beneficial effect of collagen peptide supplement on anti-aging against photodamage. Korean J Food Sci Technol 41: 441-445

Kim JS, Kwon CS, Son KH (2000) Inhibition of alpha-glucosidase and amylase by luteolin, a flavonoid. Bopsco Biotechnol Biochem 64: 24582461

Kim SH, Jang SD, Lee KY, Sung SH, Kim YC (2009b) Chemical constituents isolated from Polygala japonica leaves and their inhibitory effect on nitric oxide production in vitro. J Enzyme Inhib Med Chem 24: 230-233

Kou J, Si M, Dai G, Lin Y, Zhu D (2006) Antiinflammatory activity of Polygala japonica extract. Fitoterpia 77: 411-415

Lee EK, Chung DK (2011) Studies on the behavioral pharmacology of the antidepressant effect of Polygala japonica Houtt.. Kor J Herbology 22: 129-146

Lee KK, Kim JH, Cho JJ, Choi JD (1999) Inhibitory effects of 150 plant extracts on elastase activity, and their anti-inflammatory effects. Int $\mathrm{J}$ Cosmetic Sci 21: 71-82

Li W, Li Y, Yang J, Xiao P, Qian Z (1996) A study on chemical constituents of Polygala japonica. Natural Product Research and Development 8: 1-4

Lim RJ, Do BS (2001) Korea medicinal plant dictionary. Yeogang, Seoul, pp 521

Meyer K (1947) The biological significance of hyaluronic acid and hyaluronidase. Physiological reviews 27: 335-359

Pak WM, Kim KBWR, Kim M, Kim J, Park J, Park JH, Bae NY, Park SH, Ahn DH (2016) Anti-melanogenesis and anti-wrinkle effects of Sargassum micracanthum extracts. Microbiol Biotechnol Lett 44: 19-25

Perlish JS, Lemlich G, Fleischmajer R (1988) Identification of collagen fibrils in scleroderma skin. J invest dermatol 90: 48-54

Seo YS (1988) Characteristic and application of hyaluronic acid. Polymer 12: 484-488

Sies H (1997) Oxidative stress: oxidants and antioxidants. Exp Physiol 82: 291-295

So SI (2015) Compansion of antioxidant effect according to extract solution in microtuber and potato. Dissertation, Sahmyook university

Song JS, Kim YA (2009) A study on the future market prospect of domestic functional cosmetics industry-focused on the cosmeceutical products-. The Korean society of design culture. 15: 258-271

Wang H, Gao J, Kou J, Zhu D, Yu B. (2008) Anti-inflammatory activities of triterpenoid saponins from Polygala japonica. Phytomedicine 15: 321326

Wunsch E, Heidrich HG (1963) Zur quantitativen bestimmung der kollagenase. Hoppe-Seyler's Z Physiol Chem 333: 149-151

Zhang DM, Miyase T, Kuroyanagi M, Umehara K, Ueno A (1996) Five new triterpene saponins, Polygalasaponins XXVIII-XXXII from the root of Polygala japonica Houtt.. Chem Pharm Bull 44: 810-815

Zhang DM, Shan WH (2005) Chemical constituents from roots of Polygala japonica. Chinese Trad Herbal Drugs 36: 1767 